\title{
The transmutation of bogwera in Luke 2:21 in the 1857 English-Setswana Bible
}

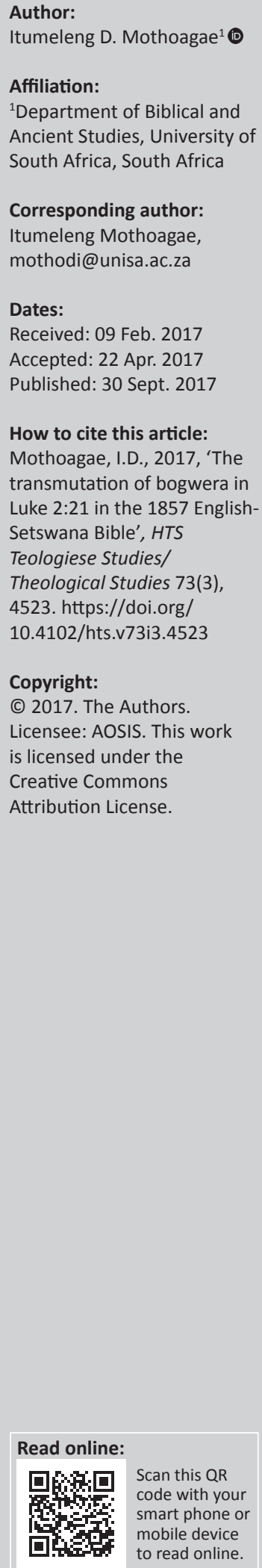

In her article on 'translating ngaka' (diviner-healer), Musa Dube argues that in the writings of Robert Moffat and subsequently in his translation of the Bible into Setswana, the person of the ngaka, rather than being portrayed as occupying a central and positive role in Setswana culture, is relegated to a marginal position and is even depicted as evil and an imposter. The article seeks to argue that firstly, there is a fundamental connection between ngaka and bogwera in Setswana tradition. This is because ngaka performed the rite of initiation and was a central figure in the circumcision (rupa) of those undergoing the rite of imitation. Secondly, in his 1857 English-Setswana Bible Moffat alters the word bogwera in Luke 2:21. In representing and translating bogwera as circumcision in Luke 2:21 Moffat rewrites and reorders the political, economic and religious beliefs of Batswana. It is in the transmogrification of bogwera in Luke 2:21 that an act of hybridisation and creolisation takes place through the ordering of the Batswana cosmology and culture. I would further argue that not only did this marginalisation colour the perceptions of the Batswana regarding bogwera, but also that the translated text was used as a tool to disrupt, marginalise, replace, subvert and colonise the spiritual spaces of the Batswana. Furthermore, the article attempts to critically engage with the translated text from an ideological criticism within postcolonial theory, engaging with the fundamental question: why did Moffat translate and alter bogwera as circumcision rather than using the proper word which is rupa (circumcision)? Selected letters published in the newspaper Mahoko a Becwana (Words of Batswana) are quoted and discussed, as it is in these letters that we are confronted with an act of hybridisation and creolisation. The letters also point to the effects of such a translation and transmogrification as a discursive tool to reorder and to pervert the Batswana cosmology and culture. In translating and altering circumcision as bogwera Moffat performs an act of mutation of meaning. It is in this morphing of bogwera into something that is charged with negativity in order to reorder and rewrite through an exercise of transmutation that Moffat attempts to subvert and to indoctrinate, resulting in the subversion of the spiritual spaces of Batswana.

\section{Introduction}

What wisdom, what meekness are necessary to him who proposes to introduce the elements of a spiritual empire, to sweep away any refuges of lies, to prostrate idols and altars in the dust, to abolish rites and ceremonies, to transform barbarous and antiquated judicial systems, and after the apostolic fashion, to turn the world upside down. (Moffat 1842:258)

Prior to the arrival of the evangelists in Batswana, the belief system of Batswana was referred to as ngwao ya Batswana [tradition or customs]. It is in the tradition and customs that we find the rich oral tradition that was passed on from one generation to the other through various rituals and folklore. For Batswana tradition, education and belief are intrinsically linked. Ngwao ya Setswana then means that tradition and culture of the people; lifestyles; religions; injuries; views on life, that is accurate, chosen by the ancestors of our nation to manage public lives; raising, provide; to guide and teach generations of people about life, respect yourself as a person with humanity and selfesteem as people be distributed with personality. This includes inheritance, can be of what already exists, or the knowledge needed to design, carpentry, construction, weaving and build some things that reflect the nation. All this is designed by the nation or tribe and in the composition of their language.

The arrival of the London missionaries among the tribe of Batswana called Batlhaping in Dithakong ('Lattakoo') and the various missionary societies such as the Wesleyan and the Lutheran Societies in the rest of the Batswanaland did not only affect ngwao ya Batswana but it also altered the administrative aspects of Batswana. Because Setlhaping dialect was the first to be translated, these societies 
depended on these texts. During the 1820s, with the help of a few multi-lingual Griqua and Batlhaping at Kuruman, the London Missionary Society missionary, Robert Moffat, developed an orthography for Setswana that was adopted by most other missions in the Sotho-Tswana interior. The Kuruman press produced a large volume of Setswana books, and early missionaries in the interior used the London Missionary Society publications as their primary texts for learning Setswana and evangelising at various Batswana communities. Robert Moffat had in 1825 gone to Kuruman, Namaqualand, to work among the Batswana people. Moffat used his sojourn in Cape Town to learn Dutch, which he employed for preaching and for prayer (to the colonists), until he mastered the Tswana language in 1827. After establishing himself in Kuruman in 1826, Moffat relied entirely on interpreters for communicating in Setswana and also still depended heavily on Dutch. Through his journals, Moffat provided highly interesting glimpses into the efforts that eventually yielded his Setswana translations. The process was a difficult and tedious one, made no easier by the fact that the time for interpretations and translations was usually at the end of a long day of manual labour. Moffat (1842) states:

The acquisition of the language was an object of the first importance. This was to be done under circumstances the most unfavourable, as there was neither time nor place of retirement for study, and no interpreter worthy the name. A few, and but a few words were collected, and these very incorrect, from the ignorance of the interpreter of the grammatical structure either of his own or the Dutch language, through which medium all our intercourse was carried on. It was something like groping in the dark, and many were the ludicrous blunders I made. The more waggish of those from whom I occasionally obtained sentences and forms of speech, would richly enjoy the fun, if they succeeded in leading me into egregious mistakes and shameful blunders; but though I had to pay dear for my credulity, I learned something. (p. 291)

In his study of the letters and journals of Robert and Mary Moffat, Schapera contends that that Moffat remained ignorant of Batswana beliefs and traditional customs throughout his ministry, condemning them all indiscriminately as vicious and perverted nonsense (Moffat 1951:xxvii). Moffat himself states that some of the Batswana rituals seemed to be similar to Mosaic laws from the Old Testament: 'like shells without the kernel'. He also states repeatedly that he came up against the sayings and acts of a so-called 'rainmaker', to whom the Batswana attached great value (Moffat 1842:263-266, 311). The name 'Moffat' has an important place in the history of Bible translation. He is associated with the first complete Bible into the Setswana language. That history can be sketched exactly from 1825, when he translated a catechism along with John 3 and other passages of Scripture into Setlhaping, a Setswana dialect of the Batlhaping people of the Dithakong area (Moffat 1842:444). This first ever set of translations in Setswana was sent to Cape Town in 1825 to be printed. It was published by the London Missionary Society in 1826 (Coldham 1966:694). Judging by the fundamental change that these texts later had on the
Kuruman mission, this accident significantly interrupted Moffat's work. The next publication was the book of Luke in 1830. In 1840, the complete New Testament in Setswana was published by the British Foreign Bible Society. A year later, the New Testament with Psalms followed. Finally, in 1857, the whole Bible was completed and published (Hermanson 2002:13). It is within this context that the translation of the Bible into Setswana emerges. The present article seeks to argue that the transmogrification of bogwera in the translation of the Bible. To achieve this Moffat first begins with the representation of (di)ngaka divinerhealer(s) as agents of darkness or servants of Satan sought to undermine the role of these diviner-healers within the tribe of Batlhaping in that it violated and subverted the spiritual spaces occupied by dingaka in the life of the community. In the present article I follow Mojola's analytical approach. Mojola (2004) states:

postcolonial approaches to translation ... are primarily concerned with the links between translation and empire or translation and power as well as the role of translation in processes of cultural domination and subordination, colonization and decolonization, indoctrination and control and the ... hybridization and creolization of cultures and languages. (p. 101)

Luke 2:21 in the 1830 and 1857 versions of the Moffat Bible serves as an illustration of the importation of a concept with spiritual and cultural significance into a target language in a way that separates it from its religious landscape and social constructs. Readers' letters to Mahoko a Becwana (Words of Batswana) during 1883-1896 provide an illustration of the effects of the transmutation of the concept of bogwera. The divide in the letters is evident, those disallowing their children to attend the rite of initiation and those defending their tradition. Diviner-healer(s) played a significant role during the rite of initiation. The importing of bogwera as a concept embedded within the Setswana religious landscape and with social significance for the Batswana into a biblical text (Lk 2:21) not only subverted the function of the concept in terms of the physical, psychological and conceptual spaces, but it also became a discursive tool, and an instance of cultural domination and subordination, colonisation, indoctrination and control of another culture and language. Therefore, the article does not seek to do an exegesis of Luke 2:21 of the 1857 EnglishSetswana Bible translated by Robert Moffat. Rather, the article attempts to embark on an ideological criticism by using the 1857 English-Setswana Bible as translated by Robert Moffat within translation.

1.Mgadla and Volz (2006) cover page, "Mahoko a Becwana (News/words of Batswana), a Setswana-language newspaper; published by missionaries of the London Missionary Society at Kuruman between the periods of 1883-1896. The majority of the writers were members of congregations in what are today South Africa's Northern Cape Province and Northwest Province, but many also wrote from as far away as the Transvaal, Orange Free State and the Bechuanaland Protectorate. Most of the writings were letters to the editor but their intended audience was primarily other Batswana readers of the ewspaper. They wrote on audience was primarily other Batswana readers of the newspaper. They wrote on a wide range of topics of concern to literate, mission-educated Batswana at that time, including mission work, theology, standardisation of written Setswana, cultural change and the European colonisation. Their letters were also often written in response to other letters or missionary articles, producing lively debates on a number of controversia issues. These writings offer a rare and revealing glimpse of the conversations that took place among literate Africans during a crucial period in the formation of modern South Africa and Botswana'. 


\section{Ngwao (tradition and customs)}

Oral tradition was and continues to be central in the spiritual life of the Batswana. It is in ngwao ya Setswana that we also see the intersection of politics, economy and religion, as integrated in the life of the community, not separate as in the western colonial Christianity. Through folklore, marriage ceremonies, funeral rites, naming ceremonies and so on, memory is a vital means of passing on the traditions and beliefs of the Batswana. It is at this point that a definition of ngwao is critical in order to understand the function of tradition and custom amongst the Batswana as well as to locate the various roles played by various members of the community and the significance of certain practices within Setswana culture. This will later be linked with the missionaries' attitudes towards these traditions and customs, which subsequently led to the marginalisation of these spiritual spaces, and an attempt to replace, subvert and colonise them.

In his book Ngwao ya Setswana (1985), Mogapi (1991) defines ngwao in the following manner:

Ka ngwao go tewa 'segaabo batho; mekgwa ya botshelo; ditumelo; ditemalo; maikutlo ka ga tsa botshelo' tsela e e thomameng, e e saleng e ikgethetswe ke batlapele ba setšhaba go tsamaisa matshelo; go godisa, go tlamela; go kaela le go ruta dikokomana tsa setšhaba seo ka ga botshelo le go itlotla jaaka batho ba ba nang le botho. Se se akaretsa boswa, e ka nna jwa dilo tse di setseng di le teng, kgotsa jwa kitso ya go dira -go thama, go betla, go bopa, go loga le go aga dilo dingwe tse e leng seipone sa setšhaba seo. Tse tsotlhe di logeletsweng ya setšhaba seo le mo ditlhamong ka puo eo. ${ }^{2}$ (p. 1)

This definition reveals the complexity of the traditions and customs of the Batswana. These traditions were the very fibre of the communities. They were concerned with a person as a whole, and his or her relationship with the tribe and nature. In these traditions and customs we find the richness of orality, knowledge construction, morality and spirituality, expressed in folklore, mythology and superstition. Put differently, ngwao sustains and develops a type of behaviour that one has to demonstrate: correct and moral behaviour that will enable those who carry it out in the right manner to achieve their intended goals and to respect and treat other traditions and customs with the respect they deserve (1991:1).

Mogapi further states that ngwao [tradition and custom] and thuto [education] are interconnected; in his view, ngwao is education, and education is ngwao (1991:2-3). Mogapi argues that this interconnectedness between ngwao and thuto can be seen in the expressions of tradition such as household matters; chieftaincy; language; praises; songs; religion; rites relating to initiation; marriage, childbearing and motherhood; diviner-healers and healing; death; agriculture; the names of stars; and the names of months. It is for this reason that, in

2.Tradition and culture of the people; lifestyles; religions; injuries; views on life, that is accurate, chosen by the ancestors of our nation to manage public lives; raising, provide; to guide and teach generations of people about life, respect yourself as person with humanity and self-esteem as people be distributed with personality. This includes inheritance, can be of what already exists, or the knowledge to do to design, carpentry, construction, weaving and build some things a reflection of that nation. All this is designed by the nation or tribe and in the composition of thei language. (my own translation)
Mogapi's view, ngwao and thuto cannot be separated, because through tradition people are able to evaluate, discern and measure their actions and behaviour in terms of what they have learned in the household, within the tribe and at the initiation schools. ${ }^{3}$ It is in Ngwao that a reflection of tribe in terms of morality, religiosity, structural systems, how people behave, how they treat one another and are treated by their kgosi. In short it is a mirror by which the whole tribe can evaluate itself. Thus, according to Mogapi, it is in ngwao and thuto that the two components, namely oral tradition and customs, are expressed through the three components, namely religious, political and economic life of Batswana.

\section{Contextualising bogwera: Through the eyes of ngwao ya Setswana}

Prior to the arrival of Western colonial Christianity, Batswana made a distinction between a boy and a man. It was understood that a boy was an uncircumcised man. Bogwera as a religious and cultural practice was an integral part of the community's spiritual life and expression, and in its practice the connectedness of politics, economy and the religious expression of Batswana. Bogwera, like many other institutions within ngwao ya Setswana, had its laws, mythology and superstitions, and it is from these that the missionaries such as Moffat found it distasteful and that it needed to be replaced with a 'civilised' way of life. The political aspect of bogwera one would contend was in the role of the royal family, the social hierarchy between lineage and the role the initiates will play in the political landscape of the community. The economical aspect of bogwera was the contribution aspect of the families participating in the ritual that was in terms of the food and the centrality of the royal family in the practice. The religious aspect was expressed in the continual presence of the divinerhealer from the very beginning until the end of the ritual, and the presence of badimo (ancestors) and Modimo. ${ }^{4}$ At the centre of this is the belief in the ancestors as the protectors and providers of the community. The spiritual aspect of the community is expressed in the understanding of the divine as being hierarchically ordered. Mogapi explains the belief system of Batswana by pointing out that there is a hierarchy within the divine. He states:

Mo tumelong ya Setswana badimo ba ne na thatlologana go tloga ka Modimo wa leokaoka, go ya go tsena ka batsadi ba motho. Thatlologano e e ne e tsamaya jaana: ${ }^{5}$

Modimo wa leokaoka [Modimo of the heavens]

Badimo ba morafe [ancestors of the tribe]

(ba ba nnang kwa Lentsweng la Badimo) [living were the voice of the ancestors resides]

3.I use the word 'school' for lack of a better word. These were not focused on the intellect of a person, but rather on the human development of a whole person.

4.I have reservations in referring to Modimo as God, as the two are distinctly different. The Setswana understanding of Modimo is that of a gender-neutral figure, while the Christian understanding of God is a gendered one. It is on this basis that I am intentionally referring to Modimo rather than God (cf: Mothoagae 2014:149-168 Ntloedibe-Kuswani 2001:78-97). 5.In Setswana tradition and belief, the ancestors formed part of the hierarchy of the
divine, starting with Modimo in the heavens to the living parents of an individual. divine, starting with Modimo in the heavens to the living parents of an individual.
This meant that to treat your parents with respect and honour was respecting Modimo as they are the living ancestors. 
Dikgosi tse di thokafetseng [The Kings that have departed]

Kgosi ya motlha oo [The living King]

Borremogolo ba ba thokafetseng [The elders that have departed]

Borremogolo ba ba tshelang [The living elders]

Batsadi ba me [The living parents]. (pp. 135-136)

It is critical to understand how discourse and rhetoric worked in the process of domesticating, marginalising and replacing the institution of bogwera for the purposes of colonisation through Christianity. It is for this reason that the following questions could be asked: Why did the missionaries such as Moffat and Wookey oppose initiation rites? Did they understand the spirituality of the Batswana? Were they ignorant of the religiosity of the Batswana? Did these spiritual spaces maintain resistance against Western colonial Christianity?

Schapera refers to Moffat as a man of amazing zeal and energy, devout, uncompromising and fearless. He was essentially evangelical, holding that the missionary's primary task was 'to teach poor heathen to know the Saviour'. He considered other interests, however praiseworthy, irrelevant (as for instance Philip's activities on behalf of the oppressed native of the Cape). He remained ignorant of the Batswana beliefs and traditional customs throughout his ministry, condemning them all indiscriminately as vicious and perverted nonsense.

\section{Translating ngaka and attempts to replace, subvert and colonise spiritual spaces}

Every kgosi (King) $^{6}$ had diviner-healers, who occupied a special space in the religious life of the community. Furthermore, dingaka tsa dinaka [diviner-healers using bones known as ditaola] were key players in public affairs and the public health of the whole community (Moffat 1842:208; Schapera 1938:70). According to Schapera, because the $k g o s i$ was mmabatho [mother of the nation], motswadintle [the person from whom all good things come], he was responsible for the well-being of the nation (Tribe). It is for this reason that he was referred to as the keeper of dipheko tsa morafe [the sacred medicine of the community]. These medicines were utilised for the common good of the community and included medicines to cleanse the land to ensure a successful rainy season (Schapera 1938:70). Schapera further states that a closer look at history reveals cases where the Kgosi was the principal ngaka ya moroka [diviner-rainmaker]

6.It is essential to take note that in Setswana Kgosi is a King while his brothers or his sons are referred to as Kgosana [chief]. The understanding that they are chiefs was constructed by the western colonial production of knowledge suggesting that they could not be at the same level as their imperial monarch, who led and governed the whole nation. While in Setswana brothers could break away from their tribe to start their own tribe and that was not seen as being against or rebellious to start their own tribe and that was not seen as being against or rebellious towards their elder brother, it was an acceptable norm to do that. This translation of Kgosi as Chief points to the discursiveness and the power of written language. The King like in western thought was born into the royal family and ascended into the throne after the death of their father the King. At times the sister could be King if she was the eldest, in some cases the queen mother would be asked to take the throne for a while until her son is of age to rule. An example of such is Mantatees. because he was the administrator of rainmaking rituals (1938:70).

The rituals performed by both $k g o s i$ and ngaka were aimed at uniting the people, and they were the link between them that proved to be a problem for the missionaries. Dube argues that given the scarcity of rainfall over the lands of the Batswana, the ngaka ya moroka [diviner-rainmaker] was an important figure (Dube 2014:160). The purification of the land, as already stated, was performed by dingaka tsa baroka [diviners-rainmakers]. As a result, they were visible in the community and were viewed by Moffat as standing in the way of Western colonial Christianity, being seen to reinforce the veneration of badimo instead of the Christian God. In their book, Robert and Mary Moffat (1951) state the following regarding the Batswana religion:

Apart from their use of magic. The Ba Tswana had a welldeveloped system of religion. The dominant cult was the worship of ancestral spirits (badimo). Each family was held to be under the supernatural guidance and protection of its deceased ancestors in the male line, to whom sacrifices were offered and prayers said on all occasions of domestic importance. (p. xxi)

Why would Moffat see the ngaka or dingaka as a threat to his own religion? The answer lies in the encounter between himself and the ngaka, particularly the moroka, the priestly diviner-healer who specialised in rainmaking rituals. I would argue that because this ritual was an integral part of the religious life of the Batswana, it constituted Moffat's most challenging cultural translation project. The ngaka was the prototypical rival of the Christian missionary, for he was a diviner-healer who ensured the welfare of the community by means of divine powers, through the veneration of the ancestors (badimo).

In his book Missionary Labours and Scenes in Southern Africa (1842), Moffat dedicates a full narrative chapter to the ngaka, and the moroka particularly. The main character in the narrative is the ngaka, and the community is presented as the supporting characters. The opposing character in the narrative is Moffat himself, his colleagues and of course the weather. The scene is the land, which is portrayed as parched, in the grip of persistent drought that has left livestock either dead or emaciated. This is the setting for the drama involving the translation of the word ngaka.

Moffat acknowledges the influence of the ngaka in the public space, and it is in this chapter that we are exposed to his translation agenda. Moffat (1842) has the following to say about the ngaka:

In every heathen country the missionary finds to his sorrow, some barriers to his usefulness, which require to be overcome before he can expect to reach judgement of the populace. Sorcerers or rainmakers, for both offices are generally assumed by one individual, are the principal with whom he has to contend in the interior of Southern Africa. They are ... our invertebrate enemies, and uniformly oppose the introduction of Christianity among their countrymen to the utmost of their power ... they constitute 
the very pillars of Satan's Kingdom, in all places where such impostors are found. By them his (Satan's) throne is supported and the people kept in bondage. The rainmaker is in the estimate of the people no mean personage, possessing an influence over the minds of the people, superior even to that of their king, who is likewise compelled to yield to the dictates of this arch-official ... Each tribe has one and sometimes more. (p. 208)

Moffat clearly associates the dingaka with the realm of darkness, viewing them as agents of Satan who prevent the Batswana from accepting the 'word of God'. His translation of dingaka as 'sorcerers' did not even pretend to be faithful to its source culture, but instead formed part of the project to 'overcome' the 'barriers' and constituted a violent act of rewriting the Other from a Western colonial Christian worldview.

Dube (2014) makes the following observation:

It was in this public capacity that dingaka tsa baroka were visible forces to missionaries and regarded as opponents pf the Christian faith. They were seen to reinforce the recognition of badimo instead pf the Christian God. Robert Moffat dedicates more than a chapter to dingaka tsa dinaka, specifically the moroka. It is a full narrative construction with leading, opposing and minor characters with a plot, setting and climax. (p. 160)

This begs the question: why did Moffat dedicate a full chapter to dingaka as the apparent reinforcement of the belief system of the Batswana? The above citation points to text as a technology of power and a tool to domesticate and to 'other', as Moffat begins his translation project of rewriting the positive role fulfilled by the dingaka in their society as a negative one. Under the power of his pen the influential, revered, priestly healer-doctors are rewritten as 'sorcerers', 'rainmakers', 'impostors', the pillars of Satan's kingdom, supporters of Satan's throne, who keep their communities in bondage. Their herbal knowledge, which had sustained communities from time immemorial, is relegated to the category of 'nostrums' (Moffat 1842:218). The community is portrayed as foolish, as followers of Satan.

Through the literature Moffat reinstalls his colonial thought and trajectories within the subconscious of the target audience, thus creating a double consciousness. Furthermore, it is imperative to locate Moffat within the context and time in which he operated, because the translation he produced was shaped by the system that produced him. Thus, through his project of the vernecularisation of the Bible, Moffat uses literature as an attempt to marginalise dingaka; it was also an exercise of manipulation, alteration, rewriting and cultural translation to serve particular purpose of evangelisation (Cf. Arduini \& Nergaard 2011:8-15; Bassnett \& Lefevere 1990:1-13; Gentzler 2001:187-203).

As already stated, the ngaka was central in the life of the Batswana community. It was through him or her that the link between those in the realm of the divine and the living was sustained. It was the ngaka who repaired relationships among members of the community and between the community and the ancestors. The spiritual spaces were occupied by the ngaka, and it was the ngaka who performed certain rites within these spiritual spaces. The arrival of the missionaries among the people was to prove detrimental to their religious system. The missionaries would undermine the role and centrality of the dingaka within the community, and literature was to be the vehicle for subverting, replacing and colonising the very space occupied by the dingaka in the community.

Why use literature to marginalise the dingaka? I would argue that missionaries such as Robert Moffat saw the dingaka as a hindrance to 'converting' the Batswana to Western colonial Christianity. Ntloedibe-Kuswani maintains that it is in Moffat's rewriting that we see a departure from the conception of the diviner-healer as occupying a positive role and contributing to the well-being of Setswana society in relation to its members, the environment and the divine powers (Ntloedibe-Kuswani 2000:502).

Musa Dube (2014) critically engages with the use of literature to undermine and marginalise the dingaka, and states:

Contemporary translation studies now highlight the power relations and ideological positions of the translator, publishers, target audiences, patrons, and other stakeholders that shape translations. (p. 158)

Power relations embedded in the process of translation became a technology of power. The missionaries, through literature, exercised these power relations, the outcome of which, I would argue, was the violation of the spiritual spaces and the marginalisation of the dingaka in the life of the community. I would further argue that this not only affected the spiritual leaders of the community, in the persons of the dingaka, but also influenced the role of the dikgosi in the spirituality of the people as unifiers, protectors, intercessors and custodians of the tradition and customs of the Batswana.

Dube highlights the zeal of the missionaries, who considered themselves bound to spread the word of their god and recognised the importance of literacy in influencing the Batswana, which became a central tool in the process of reducing Setswana to a written language. Literacy through the translated text became a technology of power.

\section{Bogwera [rite of initiation]}

Prior to the arrival of Western colonial Christianity, Batswana made a distinction between a boy and a man. It was understood that a boy was an uncircumcised man, while a man was circumcised. The word for circumcision in Setswana is rupa. Bogwera, like many other institutions within ngwao ya Setswana, had its laws, mythology and superstitions, and it is from these that one can deduce the construction of spiritual spaces within the Setswana belief system. This was based on the understanding that through bogwera the initiates were taught the tradition and custom of Batswana. In the definition of ngwao ya Setswana as discussed earlier there is an intrinsic link between ngwao le thuto [tradition and education]; it is in both tradition and education that the preservation and passing on of tradition is actualised. Initiation schools, among other things, were reservoirs of knowledge. Those 
undergoing bogwera were taught the importance of botho [personhood]. As I will show in this section, these initiation rites were not undertaken haphazardly. To undergo bogwera one had to go through the three stages of bogwera, namely, bogwera jo bosweu [white initiation] ${ }^{8}$ and bogwera jo bontsho. According to Mogapi, bogwera jo bosweu took place 2 days before the commencement of the rite.

Mogapi further states bogwera jo bosweu was the first initiation. The name derives from white clay that the young men would apply on their bodies (Mogapi 1991:38-47). He states that the name came from the shaving of hair. The following day before departing the initiates (mangwane) gathered according to their lineage $(\mathrm{kgotla})^{9}$; they were then led by the son of the chief. The end of initiation is known as kaloso. On the last day in the morning the new initiates were told to apply letsoku (-red clay), and to put on the new skin clothes made for them (1991:45). It is at this point that they would begin the second stage of their initiation rite which is referred to as bogwera jo bontsho, other names for this stage are setsho/ sentsho, diphirwa or bophirwa [black initiation]. It took place 3 months after the first stage of their initiation. Bogwera jo bontsho is the final stage of initiation which is referred to as kaloso [graduate] ${ }^{10}$; it took place for a few days. ${ }^{11}$ Put differently, bogwera jo bontsho entails the return of the new initiation from the (merakeng) cattle post to the village or their homes. It is at this point that there will be jubilation and festivities marked with the slaughtering of cattle (1991:47). The initiation of young women is referred to as bojale. It took place within the tribe, in identified houses. The community was excluded from the spaces occupied by the initiates. Again the same thing applies here, in terms of the passing on of knowledge, tradition and religion (1991:49). Mogapi stresses the importance of understanding the integral part played by bogwera in ngwao ya Batswana. The initiates were taught the traditions and customs of the Batswana. Through initiation young boys were transformed into men of stature, who knew the law and their role within the tribe. Tradition was passed on through teaching (1991:36).

Through bogwera, initiates gained status in the tribe. It was a gateway into marriage, and participation in conversations among men. A man who did not undergo bogwera was

7.Botho is a philosophy that is grounded on the notion that motho ke motho ka batho (a person is a person through others), it is for that reason that in Setswana there cannot be a person in the community who should go hungry together with his cannot be a person in the community who should go hungry together with his family. For the Batswana Rather it was behaving in a manner that acknowledges other people. This included the expectations of society and what made nations. It can be said that these schools played a fundamental role in the identity formation of those entering the initiation process.

8.It is imperative to understand that the names were given to differentiate the various stages the young men underwent during the rite itself.

9.In Setswana there is a hierarchy in the lineage. By putting them in terms of thei lineage this was to remind them about the hierarchy within their lineage. It is also important to point out that in Setswana if the younger brother has a child before his older brother, the child of the older brother is older to the one older than him because his father is the elder one.

10.The word graduate limits the etymological meaning of the word kaloso as it did not mean to graduate in the literal sense of the word; rather it is an acknowledgement, recognition and acceptance into manhood.

11.It is important to take note that after the rite of initiation the men would not return home immediately. They would live at a place referred to as merakeng [cattle post]. regarded as a boy, who would be excluded from conversations among men, who would not be allowed to marry, and who would be considered a boy all his life.

The sacredness of bogwera is reflected in the secrecy about where it is held, and what happened during the initiation. Everyone participating in this rite was sworn to secrecy and was expected to never disclose what took place (1991:36). The exclusion of those who have never undergone initiation points to the sacredness of the ritual. On the face of it, this exclusion may have seemed unfair, yet it is in these institutions that tradition was kept intact and passed on from one generation to the next. It was precisely such institutions that the missionaries disapproved of.

The ngaka played an important role in the rite and healed the wounds of those having undergone thupiso [circumcision] (1991:40). The criticality of the ngaka in the rite of passage was seen in his presence - I would argue that it points to the sacredness of the space at the time. It is for that reason that the rrathipana [surgeon] could not perform the circumcision without the ngaka. The role of the ngaka included anointing the circumcised with a traditional medicine immediately after removal of the foreskin, and the foreskins are handed over to the ngaka (1991:40).

The boys lived apart from the community for approximately 3 months. The space they occupied was looked after by makgajane or bagokane - the shepherds of the gates or doors who during this time were not allowed to go home or be intimate with a woman. Transgression of this rule resulted in punishment or a fine of one cow (1991:41).

At each door there was an old man, referred to as molobe-ka Sekgatla or rra-kgejana [the leader in the knowledge of bogwera], known to have immense knowledge about Setswana tradition, law, mythology and religion, more particularly about bogwera. Mogapi states that there was also a molobe [translate] that was of royalty, and at times a brother or relative of the Kgosi. He was referred to as mogokgo or rrakgejana [principal] of all of them and gave instructions about the day-to-day arrangements relating to the initiation. He also monitored the slaughtering and the distribution of the meat. The kgosi and the fathers of the young men attending the rite of passage were allowed to visit the young men, but they were not allowed to stay long. The rite of passage would only take place if the kgosi had a son. If the kgosi did not have a son, one of his brother's ${ }^{12}$ sons would be the leader of the initiates and gather them. On arrival at the site of the initiation they are divided into two groups (1991:36).

The end of the initiation rite is referred to as kaloso [end of initiation]. ${ }^{13}$ At the end of the initiation the young men were no longer regarded as boys, but were instead referred to as

12. Brothers here refer to what in Westerns terms would be regarded as cousins.
These are sons of his father's brothers. The Batswana consider any child born
within the paternal line a brother or sister. Children of an aunt who is the sister to the father are referred to as cousins.

13.The end of the rite of initiation (author's own translation). Kaloso happens before bogwera jo bontsho, which is the final rite to end the rite. 
dialogane, makolwanyane, kgotsa batsokwane: designations that identified them as having undergone the rite of passage (1991:47).

\section{The Moffat Bible: Luke 2:21 the transmutation of bogwera as the circumcision of Jesus}

The Gospel of Luke was the first gospel to be translated by Moffat and forms part of the available literature translated into Setswana. It was through the vernacularisation of the Bible that the missionaries sought to convert the Batswana to Christianity. Put differently, the translated texts were a tool for catechising the so-called 'heathen'. It is in these texts that we see language as a device that has the capacity to create, and it is language that has the capacity to name, define and signify the spaces it creates. It can be argued that through these three capacities language is power, and as such it is able to regulate who is allowed access and who is kept outside of the discourse and the practices that make the discourse possible. Hence, where there is language there is discourse, and in the presence of a discourse there is a consensual or relational community.

Bassnet and Trivedi (1990) argue that translation is not an isolated act that happens in a vacuum, but that it is part of an 'ongoing process of intercultural transfer', characterised by unequal relations between texts, authors and systems. The appropriation of the concept bogwera separate from its cosmological meaning in Luke 2:21 did not happen in a vacuum; Moffat had to first discredit the key, important people in the performing of the rite by first translating, naming, categorising them as a agents of darkness, and secondly, by removing the rite of initiation from its traditional understanding, suggesting it to be an act of the cutting of the foreskin. Why does Moffat transfer the Judaeo cultural tradition into the Batswana cultural conceptualisation? The translation of Luke 2:21 did not occur in a vacuum; it took place within the religious landscape and social, economic and political spaces inhabited by the Batswana. I submit that it is in transmogrification of the institution of bogwera as entailing the circumcision outside the conceptualisation of it as a move from being young men to manhood, which comes with socio-geo political, economic, structural responsibilities within the Batswana community.

\section{The Moffat Bible and the distortion of bogwera as circumcision}

In his translation of the Bible into Setswana, Moffat took the 1611 King James Version as the source text. In it, Luke 2:21 reads as follows:

And when 8 days were accomplished for the circumcising of the child, his name was called JESUS, which was so named of the angel before he was conceived in the womb. (KJV 1611)

Moffat translates the text in the following way:

Mi metsi e éit e sina héta, e ba isań nuana boguéra ka eona, eabo leina ya gague le birioa YESU, ye le biricoeng ki moengeli a e si a ithualoe mo sepopéloń (Bibela ea Boitsepho ee Cutseng Kholagano e Kholugolu le e Nca, tse ri Hetolecoeng mo Puon ea Sechuana 1857) (p. 106)
TABLE 1: Representation of bogwera as circumcision.

\begin{tabular}{ll}
\hline Representation & Author to provide heading \\
\hline 1611 King James Version: Luke 2:21 & 1830 and 1857 Moffat Bible \\
Circumcising & Boguéra [bogwera] \\
\hline
\end{tabular}

In the Table 1 translation, we can evidently see the representation of bogwera as circumcision. It is here that we are confronted with the rewriting, manipulations and transformations of Setswana tradition. In doing so, Moffat does not only appropriate bogwera, but it is also an intentional misrepresentation of it. By translating the circumcision of Jesus as bogwera, Moffat manipulates the concept and transforms it to give a totally new meaning separate from its original meaning. In so doing Moffat seeks to achieve the reordering of the spiritual spaces, the cosmological worldview of Batswana. It is in this exercise that the reordering, rewriting and then appropriation are used ultimately to indoctrinate. He does so by not making a distinction between Bogwera and thupiso [circumcision]. The question then follows: If the Batswana made a distinction between bogwera and thupiso then why did Moffat in his translation not make the distinction? Furthermore, why use western numeric (eight) as eit rather than Setswana numeric (robedi).

The transmogrification of bogwera as implying circumcision rather than using the correct word which is thupiso is an act of alteration of meaning, and that this morphing of bogwera as a concept that has a specific cosmological meaning for Batswana illustrates the beginning process of dehumanisation of nonEuropean cultures and traditions. The transmogrification of bogwera had a culture-specific function, namely to transfer imperialist cultural memory and standards to Batswana readership. However, the concept is the only thing that is appropriated, while the religious beliefs associated with the rite are further marginalised. It is in translating circumcision as a representation of bogwera that Moffat further seeks to install another occupant in the spiritual spaces of the Western colonial Christian religion as an alternative to the tradition and its cosmological worldview. The text then becomes a tool to subvert the indigenous knowledge system. To a Motswana reader, the text expresses contradictions between his or her tradition and the written tradition in the text. Firstly, (in v.21) the circumcision of Jesus takes place on the eighth day. Not only is he circumcised, but he is also given a name. While bogwera is a rite of passage from being young men to manhood, again the naming of a child happens 3 months after their birth. Secondly, the text becomes a tool for transferring the Judaeo cultural tradition through the worldview of the Western colonial Christian religion as discursive instrument to undermine ngwao ya Batswana (tradition or customs). Lastly, the tradition and education of Batswana become irrelevant and questionable. With the appropriation of bogwera in his translation, Moffat attempted to separate circumcision from the whole rite of initiation, thus eliminating and implicitly condemning the rite itself and placing Jewish circumcision in its place. The spiritual space that was occupied by the rite of initiation is then replaced by a new world order: Christian religion. The letters to Mahoko a 
Becwana reveal the dilemma experienced in this regard by writers of the letters to the newspaper. The rite of initiation is relegated to the status of idolatry; the practice is viewed as anti-Christian and uncivilised; and participating in such a rite and festivities constitutes mortal sin, as in 1 Corinthians 10 . Yet in his translation Moffat, through his use of the word bogwera, engages in intercultural transfer: his translation of Luke 2:21 supports the assertion that translation is neither apolitical nor ahistorical.

\section{Mahoko a Becwana (1883-1896) and the debates on bogwera}

In letters to Mahoko a Becwana, 1883-1896 Batswana who had 'converted' to Christianity revealed themselves at a crossroad between European culture, Christian principles and the Setswana belief system. The question to which most sought an answer was whether they should either assimilate or reject the new religion and its practices. As Mgandla and Volz point out, many were reluctant to abandon certain practices simply because they met with European disapproval, because, as members of Tswana communities, the Batswana who had become Christians still had to consider their social obligations and because many Tswana beliefs and practices were seen as civic duties (Mgadla \& Volz 2006:123).

In readers' letters to Mahoko a Becwana we are confronted with the debates relating to the relevance and significance of bogwera among the Batswana, and these debates give us a glimpse of the discourse post the Moffat Bible. They further indicate the interpretative interest, the subversion of the spiritual spaces. For the purposes of this article I will focus on only two letters.

Issue number 59 (December 1889), 29 Kuruman, 13 November 1889 Thelesho Magonaring of the Batlhware wrote the following letter:

\section{To the Editor,}

I am asking; I want to hear with understanding. Tell me that I might understand when to abstain from eating the cattle for male and female initiation participants because it is said they are sacrificial offerings. It is said that a believer is not supposed to eat them. But things from rain produced by rainmakers and traditional medicine, we eat them. We buy sorghum that has been grown with rain from rainmakers, and we even eat things from traditional healers and but the cattle of traditional healers. But you know we don't agree with those practices, and you know we say those things are just useless fabrications. So I say, which should we reject and which should we eat? Are not these all things that we despise as Christians - I mean female and male initiation rites, traditional medicine and rainmaking - and is it we who consume guinea fowl soup but claim not to eat its meat? I am,

Thelesho Maganaring, of the Batlhware. (1889:127)

The above letter, I would argue, highlights the effects of the translated biblical text as disruption, marginalisation, replacement, subversion and colonisation of the writer's spiritual spaces as represented by the disjuncture between the spiritual spaces occupied by institutions such as bogwera and the prohibition on taking food offered to 'idols' expressed in 1 Corinthians 10:14-33. Furthermore, we also see the demonisation of ngwao ya Setswana [Setswana tradition and customs], or what makes the Batswana who they are. I would argue also that the letter reveals the dilemma experienced by the 'converted' Batswana. One cannot but wonder how such teachings might have affected the family of those who had 'converted' to the new religion. The letter also hints at the departure from what the missionaries viewed as an 'uncivilised', 'heathen', 'barbaric' way of life in favour of an identity as a 'civilised' person and a 'believer' and shows the separation between those considered to be in 'darkness' and those in the 'light' of Christ. The following letter reveals resistance to conversion to a new religion.

Issue number 68 (September 1890), Mosimanyane wrote the following letter regarding the rite of initiation:

To the Editor,

I have heard of the words of your writings and I say that I have stood my ground, as I have said the missionaries want chieftainship and you disagree with me. But I know you; you are not God. You can prohibit your own children from [attending] boys' and girls' initiation, but leave mine alone. Mine will be going. I don't want [Christian] faith. It is lies that it promotes. Europeans have long been deceiving us. I am,

Mosimanyane, Maubelwe. (1890:127)

This letter is testimony to the struggle to sustain, and reclaim, the spiritual spaces occupied by the kgosi and the divinerhealers, particularly their role in the rite of initiation. The author characterises the missionaries as dangerous, as people who want to rule the Batswana - in other words, people who are attempting to colonise them. The letter questions the missionaries' authority to dictate to the writer what he should do and not do and categorises Christianity as a religion that is full of lies, which suggests that the writer asserts his religious belief in ngwao ya Setswana. The letter ends with an attack on the character of the missionaries as Europeans who are deceptive. This could serve as a warning to other readers.

The above letters point to what scholars such as Gentzler (2001:187-203) and Arduini and Nergaard (2011:8-15) refer to in translation as power relations and the ideological position of the translator. This, they argue, that major changes in translation studies relating to a departure from a focus on the source text and target languages as theoretically the correct way of approaching translation.

Furthermore, it is in the letters published in Mahoko a Becwana such as those quoted above that we see what scholars such as Bassnett and Lefevere, Gentzler and Arduini and Nergaard refer to as appropriations, manipulations, transformations, rewritings and cultural translations (Arduini \& Nergaard 2011:8-15; Bassnett \& Lefevere 1990:1-13; Gentzler 2001:187203) undertaken to serve particular purposes; this is most evident in the first letter. I will discuss these in the context of ngwao ya Setswana as instances of where translators have 
proceeded without being willing to learn the traditions and customs of the Batswana before characterising these as Satanic.

\section{Conclusion}

The article did not attempt to do an exegesis of Luke 2:21 of the 1857 English-Setswana Bible translated by Robert Moffat. Through ideological criticism of the 1857 English-Setswana, I attempted to argue that a closer ideological analysis of Luke 2:21 the Bible became a discursive tool, in rewriting and appropriating as an act of hybridisation and creolisation through the reordering Batswana cosmology and culture: the demonisation of the diviner-healers in his literature and the transmutation of various religious concepts such as bogwera, and badimo [ancestors] to name but two.

The literature by Robert Moffat points to his discontent with the tradition and culture of Batswana. In his eyes there was no need to understand the political aspects of Batswana. His aim was to make available the Bible in the language of Setswana. The project of vernacularising the Bible into Setswana was either apolitical or ahistorical. The Bible became a discursive tool to rewrite, manipulate and transform the oral tradition of Batswana. It is in Luke 2:21 of the 1857 English-Setswana Bible that we are faced with cultural transformation of bogwera as entailing circumcision.

In this article I have argued that the transmogrification of bogwera as suggesting circumcision instead of using the correct word, which is thupiso, was an act of alteration of meaning, and that this morphing of bogwera as a concept that has a specific cosmological meaning for Batswana illustrates the beginning process of dehumanisation of non-European cultures and traditions. The separation at the cosmological level included the political, economic and religious aspects as all of these intersected in the tradition and customs of Batswana. I have also argued that in translating bogwera as circumcision in Luke 2:21 Moffat did not only appropriate bogwera, but Luke 2:21 also became a discursive tool to perform a culture-specific function, namely to transfer imperialist cultural memory and standards to the Batswana readership.

I further argued that the vernecularisation of the Bible into Setswana was not an innocent exercise. Luke 2:21 serves as an example of the vernecularisation of the bible as an attempt to supress the belief system of Batswana. This I maintain is seen among other things in the translating of circumcision as a representation of bogwera. In doing so, Moffat installed another occupant in the spiritual spaces of the Western colonial Christian religion as an alternative to the tradition and its cosmological world view. The letters to the Words of Batswana point to the effects of the vernecularisation of the Bible into Setswana. I have argued that it is in these letters that we are confronted with the dichotomy between being a Christian and abandoning traditions such as the rite of initiation. The letters also point to the alteration and the morphing of bogwera into something charged with negativity. It is the transmogrification of bogwera in Luke 2:21 that illustrates the beginning process of dehumanisation of rite of initiation as an evil 'heathenism' practice as expressed in the two letters quoted above. The article has argued that Moffat's translation of the English Bible into Setswana was an act of hybridisation and creolisation, which happens through the reordering of Batswana cosmology and culture; this act was not a counterbalancing against Setswana religious practices, but rather also corrupted the spirituality and culture of the Batswana. The article has further argued that Luke 2:21 epitomises cultural evangelism, which John Mackenzie referred to as the art of civilisation (Dachs 1972:652; 1975:72).

\section{Acknowledgements Competing interests}

The author declares that he has no financial or personal relationships which may have inappropriately influenced him in writing this article.

\section{References}

Arduini, S. \& Nergaard, S., 2011, 'Translation a New Paradigm', Translation: Transdisciplinary Journal, Inaugural Issue 8-15.

Bassnett, S. \& Lefevere, A., 1990, Translation, history and culture, Cassell, London.

Bibela ea Boitsepho ee Cutseng Kholagano e Kholugolu le e Nca, tse ri Hetolecoeng mo Puon ea Sechuana, 1857, British and Foreign Bible Society, London.

Coldham, G. E., 1966, A bibliography of scriptures in African languages, The British and Foreign Bible Society, London.

Dachs, A. J., 1972, 'Missionary imperialism: The case of Bechuanaland', Journal of African History 13, 647-658.

Dachs, A. J., 1975, Papers of John Mackenzie, Witwatersrand University Press, Johannesburg.

Dube, M.W., 2014, 'Translating Ngaka: Robert Moffat rewriting an indigenous healer', Studia Historiae Ecclesiasticae 40(1), 157-172.

Gentzler, E., 2001, Contemporary translation theories, 2nd edn., Multilingual Matters, Clevedon.

Hermanson, E. A., 2002, 'A brief overview of Bible translation in South Africa', Acta Theologica Supplementum 2, 8-18.

Mgadla, P.T. \& Volz, S.C., (Translators/compilers), 2006, Words of Batswana: Letters to Mahoko a Becwana 1883-1896, Van Riebeeck Society, Cape Town.

Moffat, R., 1842, Missionary labours and scenes in Southern Africa, J. Snow, London.

Moffat, R., 1951, Apprenticeship at Kuruman: Being the journals and letters of Robert and Mary Moffat, 1820-1828, I. Schapera (ed.), Chatto and Windus, London.

Mogapi, K., 1991, Ngwao ya Setswana, L.Z. Sikwane, Gaborone.

Mojola, A.O., 2004, 'Postcolonial translation theory and the Swahili Bible', in G.L.O.R. York \& P.M. Renju (eds.), Bible translation and African languages, pp. 77-104, Acton, Nairobi, Kenya.

Mothoagae, I.D., 2014, 'The gendered God in the Setswana Bible and the captivity of Modimo: Moffat and the translating of the Bible into Setswana', Studia Historiae Ecclesiasticae 40(2), 149-168.

Ntloedibe-Kuswani, G.S., 2000, 'Ngaka and Jesus as liberators: A comparative reading', in O. Gerald, G. West \& W.D. Musa (eds.), The Bible in Africa, pp. 498-510, Brill, Leiden.

Ntloedibe-Kuswani, G.S., 2001, 'Translating the divine: The case of Modimo in the Setswana Bible', in W.D. Musa (ed.), Other ways of reading African women and the Bible, pp. 78-97, Society of Biblical Literature, Atlanta, GA.

Schapera, I., 1938, A handbook of Tswana law and custom, Frank Cass, London.

The King James Version, 1611, London: Samuel Bagster \& Sons. Logos Research Systems. Exported from Logos Bible Software, 10 March 2015. 